coarse fish, financed by the fishery interests them. selves, has commenced, and after a preliminary period of exploring possibilities, a sub-station for this special study has been set up in Cambridgeshire. Thirdly, a scheme for close co-operation between Wray Castlo and the former Avon Biological Research, situated in tho southern chalk stréam area, came into effect from April 1, 1939. Under this scheme the Avon Research henceforth becomes a part of the Association as the "University College, Southampton, Branch for Southern Rivers". It will work under the scientific guidance of the Association while retaining its own individuality of control, and the advantage of being still closely associated with the University College. Thus the position of the Association is improved in overy way, and, judging from the report on the work done, one may expect much valuablo work in the future.

\section{The Warsaw Akwarium}

The Akuarium, a new magazine published for the information of aquarium keepers in Poland, had rum only half the course, of its first volume when more serious affairs brought it to an end. The last number $(6-7)$ is a well-balanced guide to aquarium interests, dealing with mothods of constructing aquaria, circulating and hoating tho water; with natural aeration by plants and artificial acration; and with several of the creatures which have become standard inhabitants of tho aquarium. Descriptivo articles discuss among other things tho alligator, some bizarre varieties of gold-fish, and the Igyptian mouthbreeder, Haplochromis multicolor, the curious habit of which is to hatch the eggs and protect the young within the cavern of their parent's mouth. We hope that before long the Akuarium may resume publication from Warsaw under happier and more settled conditions.

\section{Social Distribution of University Education}

Is a paper on the social distribution of university education which was given before the Royal Statistical Society on March 21 (J.Roy. Statist. Soc., 102, Part 3), Prof. Major Greenwood discusses the data of whole-time higher education, with particular reference to social class and such foreign experience as is available. Even with a stringent allowance for the difference of mean intellectual levels, it appears that under present conditions a large number of children of ability fit to profit from higher education do not receive it. Prof. Greenwood, however, concludes that the primary importance of university education, so far at least as concerns whole-time university education, is vocational, and as a matter of parental and governmental philosophy this fact is complacently accepted. On this philosophy no large increase of the whole-time university population should be expected. Data, however, about part-time higher education are incomplete, and the matter is of great importance, because increased leisure, which renders higher education possible for numbers greatly exceed. ing those before, is distributed through life, not con. centrated in a few years of complete leisure. In commenting on the paper, Prof. A. M. Carr-Saunders pointed out that the number of those intellectually fit to profit from university education was very much larger than the number required to recruit tho professions. Ho believed it should be the aim of the universities to bring under their caro all who could profit fully from university education.

\section{The Lingard Festival}

THE festival recently held at Stockholm in commemoration of the centenary of the death of Per Henrik Ling, the founder of scientific gymnastics, was attended by nearly eight hundred athletes from thirty.four countries, who took part in the many displays of various methods of training and education for fitness. The general opinion of experts was that tho standard of efficiency was remarkably high and proved that the principles on which ling founded his system still offered a firm' basis for popular physical education, though the details had undergone considerablo modification in recent years. The British delegates at the Lingard and the subsequent gymnastic congress included Mr. Kenneth Lindsay, Parliamentary Secretary to the Board of Education, Lord Aberdare and Lord Dawson of Penn as repre. sentatives of the National Fitness Council of England and Wales, Lord Burghley, president of the Amateur Athletic Association, and others.

\section{A Big Sunspot}

For the third time during September, a large naked-eye sunspot group has occurred. The last of theso is a giant single spot crossing the disk between September 22 and October 4 with central meridian passage on September 28.0. Near the east limb the spot had an area corrected for foreshortening of more than 1,500 millionths of the sun's visible hemisphere. This spot is the return of an oven larger spot (Nature, Sept. 16, p. 508) which crossed the disk between August 26 and September 7.

\section{The Night Sky in October}

ON October 1 in the latitude of L,ondon, night (sunset to sunrise) lasts for $12 \cdot 3$ hours and on October 31 for $14 \cdot 3$ hours; civil twilight (the sun $6^{\circ}$ below, the horizon) shortens the night by moro than one hour. The moon is new on October 12 at 20.5h. and full (the Hunter's Moon) on October 28 at $6 \cdot 7$ h. U.T. There is an occultation of the third magnitude star, $\beta$ Capricorni, on October 20, the disappearance as seen from Greenwich taking place at $17 \mathrm{~h} .52 \cdot 0 \mathrm{~m}$. at position angle $42^{\circ}$ and the reappearance at $19 \mathrm{~h} .4 .7 \mathrm{~m}$. at position angle $282^{\circ}$. On October 28 there is a partial eclipse (magnitude 0.992 ) of the moon that is partly visible from London. The moon enters the earth's umbral shadow at $4 \mathrm{~h}$. $54 \mathrm{~m}$., reaches mid-eclipse at $6 \mathrm{~h}, 36 \mathrm{~m}$. (13 minutes before moonset at London) and leaves the umbral shadow at $8 \mathrm{~h}$. $18 \mathrm{~m}$. This lunar eclipse is preceded by a total eclipse of the sun on October 12 visible in the Antarctic Ocean south of Australia, the limits of latitude for the central line of totality lying between $60^{\circ} 0^{\prime}$ and $81^{\circ} 28^{\prime}$ south. Iunar conjunctions 